ment and provides no money in support of it. Although it is true that we are unsure of exactly how responsibilities should be spread among individuals, libraries, and the next largest units in which libraries are located, this is a very weak argument for academic librarians. Colleges and universities offer free or reduced tuition to their employees (admittedly, most consider only courses for credit in regular academic departments), free or reduced-rate tickets to cultural events and special programs, and convenient bookstores that may also offer discounts to faculty and staff. In many ways, one cannot help but be continually educated in the academic setting.

Fourth, for some CE advocates, the basic argument is that librarians should have wellorganized (perhaps, overorganized) CE because other professions have it. This is more than a little far-fetched. Many of the professions that have highly developed and/or required $\mathrm{CE}$ programs are the human services professions (medicine, social work, nursing, etc.) whose members deal every day with the health and well-being of clients. When will we give up trying to imitate this model? Academic librarians usually have access to collections that include materials about the history of the professions and about continuing education and lifelong learning. We should provide reference service for our colleagues in other settings.

Whether or not the above are really current topics of discussion, they are not the real issues.
We are lacking the infrastructure necessary for continuing education to become institutionalized within librarianship. And there appears to be a discrepancy of needs-differing perceptions by state agencies, professional associations, individual librarians, etc. We need to address some or all of the following topics: a university/higher education structure that facilitates CE, delivery systems that make individualized and off-campus study feasible, quality control, definition of roles for facilitators/resource persons, a clearinghouse or product evaluation mechanism for courseware and curriculum support materials, a recognition or record-keeping function, and many more.

Academic librarians will have to assume a larger role in continuing education generally, because their institutions are increasingly interested in this market. Colleges and universities will, I think, provide the basic continuing education framework for most disciplines. My primary concern is not how academic librarians will obtain continuing education, but, rather, how they will assume a role in providing it to others.-Ruth $M$. Katz, Denver Research Institute, University of Denver.

Editor's Note: Ruth Katz chairs the RASD CE Committee (ad hoc) and serves on the CLENE Advisory Committee. She has worked at the Library of Congress (Sci-Tech Div.) and Rutgers University Libraries and presently is a research scientist at the Denver Research Institute.

\title{
AALS/Continuing Education Committee Resolution
}

At its January 1978 convention, the membership of the Association of American Library Schools approved the following resolution on the recommendation of the Continuing Education Committee:

WHEREAS high quality library service requires a high quality staff that is continually growing and changing as the nature of library operations and librarianship changes, and

WHEREAS accomplishment of the goals of libraries requires a growing staff, and

WHEREAS the lack of organizational support has been demonstrated to inhibit staff development, while recognizing that the individual has the primary responsibility for his/her own career development,

THEREFORE, the Association of American Library Schools calls on all library bodies involved in the establishment of library standards to include a forthright statement acknowledging a library responsibility for staff development.

In brief, the position is as follows. Considering the rapid changes now occurring in libraries, staff development and continuing education programs are imperative if a library is to maintain adequate service. Initial preparation through formal education and orientation programs is not sufficient to maintain adequate staff competency. The ALA statement of policy, "Library Education and Personnel Utilization," in recognition of this fact, states, "Library administrators must accept responsibility for providing support and opportunities (in the form of leaves, sabbaticals, and released time) for the continued education of their staffs."

While library personnel retain the primary re- 
sponsibility for their own career development, libraries have a vested interest in assuring continued staff competency. Research into continued education for librarians has demonstrated that administrative support is a necessary factor in assuming adequate staff development. (See the following publications of Elizabeth W. Stone: Factors Related to the Professional Development of Librarians [Metuchen, N.J.: Scarecrow Press, 1969]; and "Administrators Fiddle While Employees Burn-or Flee," ALA Bulletin, 63 [February, 1969], p. 182-83.)

Just as libraries invest substantially in collection development, they must also invest in staff development if they are to provide quality service. It should be kept in mind that most libraries spend two to four times as much money on personnel as on the collection. Like all labor- intensive organizations, libraries must pay particular attention to maintaining and developing their human resources if they are to assure high performance.

Given that rationale, AALS believes that every type of library standard should include a forthright statement acknowledging as necessary the library's financial support for staff development. The following statement might be used as a point of departure for drafting such a standard: "The library shall provide support, financial and otherwise, at least sufficient to assure that the staff at all levels maintains currency as library philosophy, services, programs, and technology change."

For further information, contact M. P. Marchant, School of Library and Information Science, Brigham Young University (AALS Continuing Education Committee), Provo, UT 84602.

\section{ACRL Chapters}

- A dinner meeting cosponsored by the Southern California Chapter of the Association of College and Research Libraries and the Southern California Technical Processes Group was attended by 170 librarians. The meeting was held May 30 at the UCLA faculty center.

Prior to the dinner there was a cocktail hour reception for UCLA Librarian Russell Shank, incoming ALA president. Michael Gorman, head of technical services, University of Illinois at Urbana-Champaign, and coeditor of the abridged Anglo-American Cataloguing Rules, second edition (AACR II), was the featured speaker of the meeting.

In speaking on "Closing the Card Catalog," Gorman stated that the costs for card catalogs are too high and that the format is not adaptable, thus prohibiting changes. What he feels is needed is a single automated, integrated tool, which contains not only the bibliographic record of any given item but all files on that item maintained by the library. He briefly described the plans for closing the card catalog at the University of Illinois.

After his presentation, questions on $A A C R$ II were raised. He views it as the best summary of "premachine" cataloging we have, though imperfect. The current concern surrounding AACR II, in his opinion, is not with the rules themselves but rather the problems of integrating the old and new.

ACRL will have a final meeting of the year in September. Chapter membership is automatic for current ACRL members. Others wishing to join may do so upon payment of $\$ 5$ dues mailed to: Philip M. O'Brien, College Librarian, Whittier College, Whittier, CA 90608.

\section{Buy Three Dollars Worth of}

\section{Books for Each Dollar You Spend.}

Best Buys In Print is a guide to quality books available at discount prices. It is also an indispensable acquisitions tool which offers an average savings of $65 \%$ or more on 20,000 titles during 1978. BBIP belongs on the shelf next to Books In Print because it complements Books In Print in three ways:

1. It identifies sources of books that have been remaindered by original publishers.

2. It provides access to the special import and reprint titles from remainder houses, and

3. It provides information on special sales and pre-publication discounts available from original publishers.

A subscription to Best Buys In Print is only $\$ 25.00 /$ year (any four consecutive issues). Foreign postage is extra. Subscribe now and save!

PIERIAN PRESS 5000 Washtenaw Ave., Ann Arbor, MI 48104 